\title{
Nouvelles françaises du XIX siècle, Anthologie, Textes établis, annotés et présentés par Allan H. Pasco
}

\section{Ida Merello}

\section{(2) OpenEdition}

\section{Journals}

\section{Edizione digitale}

URL: https://journals.openedition.org/studifrancesi/46152

DOI: 10.4000/studifrancesi.46152

ISSN: 2427-5856

\section{Editore}

Rosenberg \& Sellier

\section{Edizione cartacea}

Data di pubblicazione: 1 octobre 2007

Paginazione: 470

ISSN: 0039-2944

\section{Notizia bibliografica digitale}

Ida Merello, «Nouvelles françaises du xix siècle, Anthologie, Textes établis, annotés et présentés par Allan H. Pasco», Studi Francesi [Online], 152 (LI | II) | 2007, online dal 30 novembre 2015, consultato il 24 novembre 2021. URL: http://journals.openedition.org/studifrancesi/46152 ; DOI: https://doi.org/ $10.4000 /$ studifrancesi.46152

Questo documento è stato generato automaticamente il 24 novembre 2021.

\section{(c) (i) (9)}

Studi Francesi è distribuita con Licenza Creative Commons Attribuzione - Non commerciale - Non opere derivate 4.0 Internazionale. 


\title{
Nouvelles françaises $d u X_{X} X^{e}$ siècle, Anthologie, Textes établis, annotés et présentés par Allan H. Pasco
}

\author{
Ida Merello
}

\section{NOTIZIA}

Nouvelles françaises $d u$ XIX $x^{e}$ siècle, Anthologie, Textes établis, annotés et présentés par Allan H. PASco, Charlottesville, Rookwood Press, 2006, pp. 487.

In una prefazione quanto mai densa e interna al dibattito teorico contemporaneo, Allan н. Pasco compie uno studio - breve, ma ricchissimo di riflessioni e di suggestioni - sulla forma della novella, partendo dalla sua definizione come genere letterario. Pur inglobando infatti in ogni secolo le caratteristiche specifiche dell'epoca, la novella mantiene sempre un insieme di elementi identificabili, declinati in maniera diversa da ogni autore. Pasco affronta così la questione dei generi, ribadendo come sia difficile applicare schemi scientifici al campo umanistico: infatti, diversamente rispetto alla natura, all'interno dei generi le forme continuano a modificarsi e il romanzo di ora ha ben poco a che vedere con il romanzo realista o barocco. Pure ritiene che una definizione sia comunque utile per poter individuare dei tratti distintivi e ne propone una della novella: «breve finzione letteraria scritta in prosa». Passa quindi al commento di ogni singolo elemento della definizione: ammette la difficoltà di quantificare la brevità, ma ritiene importante la clausola dello scritto in "prosa" per poter isolare la novella rispetto ad altre forme, come i fabliaux, che avevano una struttura ritmica. L'A. appare convinto che ogni altra modifica (grado di finzionalità, spazio descrittivo, dei personaggi, dell'intrigo, ecc.) sia del tutto marginale e insignificante rispetto alla definizione da lui proposta, e rientrante appunto in quella deriva che è propria di ciascun genere. Propone quindi quasi una trentina di novelle, con alcune "chicche", 
come Mirza di Mme de Staël, Mouny Robin di George Sand o L'inconnue di Marceline Desbordes-Valmore. 